\title{
Serum Creatinine and Uric Acid Levels in Hypothyroid Patients: A Cross Sectional Study
}

\author{
Md. Aminul Haque Khan ${ }^{1}$, Md. Ishaque Majumder ${ }^{2}$, Md. Mozammel Hoque ${ }^{3}$, \\ Md. Fariduddin ${ }^{4}$, Forhadul Hoque Mollah ${ }^{5}$, Iqbal Arslan ${ }^{6}$
}

\begin{abstract}
Background: Hypothyroidism is associated with many biochemical abnormalities including increased serum creatinine and uric acid levels. Many studies were done abroad regarding serum creatinine and uric acid levels in hypothyroid patients. We designed this study in our population for evaluation of serum creatinine and uric acid levels in hypothyroid patients. Objective: To assess serum creatinine and uric acid levels in hypothyroid patients and to find out relationship of creatinine and uric acid levels with severity of hypothyroidism. Materials and Methods: This retrospective cross sectional study to evaluate the serum creatinine and uric acid levels of hypothyroid patients and to find out relationship of hyperuricemia and hypercreatininemia with severity of hypothyroidism was done in the department of Biochemistry, Bangabandhu Sheikh Mujib Medical University, Dhaka. Results were compared with that of age and sex matched healthy euthyroid controls. Statistical analyses were performed by using SPSS for Windows version 10.0. ANOVA and unpaired 't' tests were done to see the significance among the groups and between groups respectively. Pearson's correlation coefficient test was done to see the correlation of serum creatinine and uric acid levels with the severity of hypothyroidism. Results: Mean serum creatinine and uric acid levels in cases were $1.38 \pm 0.53$ and $7.00 \pm 2.54 \mathrm{mg} / \mathrm{dL}$ respectively compared to $1.01 \pm 0.17$ and $5.21 \pm 1.35 \mathrm{mg} / \mathrm{dL}$ in controls. Conclusion: Mean serum creatinine and uric acid levels were found significantly higher in hypothyroid patients compared to controls. These findings suggest that hyperuricemia and hypercreatininemia are associated with hypothyroidism. Therefore, patients presenting with these biochemical abnormalities are recommended to be investigated to explore hypothyroidism.
\end{abstract}

Key words: Hypothyroidism, Creatinine, Uric acid, Hyperuricemia

J Enam Med Col 2013; 3(2): 84-87

\section{Introduction}

Hypothyroidism is a clinical syndrome resulting from a deficiency of thyroid hormones, which in turn results in a generalized slowing down of metabolic processes. ${ }^{1}$ It is a common metabolic disorder in general population. ${ }^{2}$ The thyroid dysfunction

increases with age, especially in women. ${ }^{3}$ The prevalence of primary hypothyroidism is $1: 100$, but it may be 5:100 if patients with subclinical hypothyroidism (normal $\mathrm{T}_{4}$, raised $\mathrm{TSH}$ ) are included. ${ }^{4}$ According to a study done by Sawin et $\mathrm{al}^{5}$

1. Professor, Department of Biochemistry, Enam Medical College, Savar, Dhaka

2. Assistant Professor, Department of Medicine, Sir Salimullah Medical College, Dhaka

3. Professor, Department of Biochemistry, Bangabandhu Sheikh Mujib Medical University, Dhaka

4. Professor, Department of Endocrinology, Bangabandhu Sheikh Mujib Medical University, Dhaka

5. Associate Professor, Department of Biochemistry, Bangabandhu Sheikh Mujib Medical University, Dhaka

6. Professor, Department of Biochemistry, Bangabandhu Sheikh Mujib Medical University, Dhaka

Correspondence Md. Aminul Haque Khan,Email: aminhkhan@yahoo.com 
hypothyroidism is a common disorder with a prevalence rate up to $20 \%$. In another cross-sectional study on twelve hundred and twelve subjects of both sexes and age 20-60 years, the incidence of subclinical hypothyroidism was $19.7 \%{ }^{6}$

Hypothyroidism is associated with many biochemical abnormalities including increased serum creatinine and uric acid levels. The serum creatinine concentration increases in hypothyroid patients due to reduction of glomerular filtration rate because of hemodynamic changes in severe hypothyroidism. ${ }^{7}$ Serum creatinine level may also be increased due to hypothyroid myopathy. Hypothyroidism, although rare, has been reported as a definite and authentic cause of rhabdomyolysis. As a result, hypothyroidism must be considered in patients presenting with acute renal failure and elevated muscle enzymes. ${ }^{8}$ There is high prevalence of hyperuricemia and gout in hypothyroidism. In hypothyroidism the hyperuricemia is secondary to a decreased renal plasma flow and impaired glomerular filtration. ${ }^{9}$

Mooraki \& Basani ${ }^{10}$ reported a case of a young male hypothyroid patient with an elevated serum creatinine level $(2.3 \mathrm{mg} / \mathrm{dL})$, markedly elevated TSH level, severe hypercholesterolemia, hyperuricemia, and a creatinine clearance of $58 \mathrm{~mL} /$ minute. The patient started on levothyroxine supplementation and six weeks after thyroid replacement therapy his serum creatnine had declined to $1.4 \mathrm{mg} / \mathrm{dL}$ with an estimated creatinine clearance rate of $65 \mathrm{~mL} /$ minute. This was accompanied by reduction in serum uric acid and cholesterol levels. Eighteen months later his creatinine had further declined to $1.0 \mathrm{mg} / \mathrm{dL}$.

As hypothyroidism is associated with many biochemical abnormalities, it is of paramount clinical importance to have proper knowledge of these abnormalities and accurate estimation of these biochemical parameters is very important and useful for clinical management of the patients.

Many studies were done to assess serum creatinine and uric acid levels of hypothyroid patients. But, as far we know, no such study was done in our population. So, we designed this study in our population for evaluation of serum creatinine and uric acid levels in hypothyroid patients and that might be helpful for clinical management of hypothyroid patients with hyperuricemia and hypercreatininemia.

\section{Materials and Methods}

This cross sectional study was done in the department of Biochemistry, Bangabandhu Sheikh Mujib Medical University (BSMMU), Dhaka during the period of January 2004 to December 2004 to evaluate the serum creatinine and uric acid levels of hypothyroid patients and to find out relationship of hyperuricemia and hypercreatininemia with severity of hypothyroidism and the values were compared with that of age and sex matched healthy euthyroid subjects. Clinically and biochemically newly diagnosed 80 hypothyroid patients of both sexes, age 20 to 60 years, with no history of thyroxine in the last 3 (three) months and not taking hypolipidemic drugs were included in the study. Patients with chronic renal failure, diabetes mellitus, liver diseases, chronic diseases, pregnancy and age less than 20 and more than 60 years were excluded. Hypothyroidism was diagnosed by clinical history, physical examinations and relevant laboratory investigations. Patients with low $\mathrm{FT}_{4}$ and high TSH levels were defined as hypothyroids. Subclinical hypothyroid patients (high TSH and normal $\mathrm{FT}_{4}$ ) were excluded from the study. Total 111 subjects were included in the study and out of them 80 overt hypothyroid patients were grouped as cases (Group I) and age and sex matched 31 euthyroid subjects were grouped as normal controls (Group II). Cases were further grouped on the basis of their serum TSH concentrations into Group A (TSH level 5.01-50.00 $\mathrm{mIU} / \mathrm{L}$ ), Group B (TSH 50.00-100.00 $\mathrm{mIU} / \mathrm{L}$ ) and Group C (TSH level > $100.00 \mathrm{mIU} / \mathrm{L})$. Specimen was collected taking aseptic measures, allowed to clot, serum was separated and analyzed for creatinine and uric acid levels.

Serum TSH and $\mathrm{FT}_{4}$ were estimated by microparticle enzyme immunoassay (MEIA) method by Aboott AxSYM System autoanalyzer. Serum creatinine level was estimated by using creatinine reagent by alkaline picrate method by micro-flow cell photometer (ERMA INC; AE-100F) and serum uric acid level was assayed by using uric acid reagent by enzymatic endpoint method as stated by micro-flow cell photometer (ERMA INC; AE-100F).

\section{Statistical analysis}

Statistical analyses were performed by using SPSS for Windows version 10.0. Mean values of the findings were compared among and between groups. 
Analyses of variance (ANOVA) test and unpaired ' $t$ ' test were done to see the significance among the groups and between groups respectively. Pearson's correlation coefficient test was done to see the correlation of serum creatinine and uric acid levels with the severity of hypothyroidism. 'p' values $<0.05$ were considered significant.

\section{Results}

Table I shows the comparison of the serum creatinine and uric acid levels between the cases and the controls. Mean serum creatinine and uric acid levels in cases were $1.38 \pm 0.53$ and $7.00 \pm 2.54 \mathrm{mg} / \mathrm{dL}$ respectively compared to $1.01 \pm 0.17$ and $5.21 \pm 1.35 \mathrm{mg} / \mathrm{dL}$ in controls. Mean serum creatinine and uric acid levels were significantly increased in cases as compared to controls.

Table I: Serum creatinine and uric acid levels of study subjects

$\begin{array}{lccc}\text { Parameters } & \text { Cases }(\mathrm{n}=80) & \text { Controls }(\mathrm{n}=31) & \text { 'p' values } \\ \text { Serum creatinine }(\mathrm{mg} / \mathrm{dL}) & 1.38 \pm 0.53 & 1.01 \pm 0.17 & <0.001 \\ \text { Serum uric acid }(\mathrm{mg} / \mathrm{dL}) & 7.00 \pm 2.54 & 5.21 \pm 1.35 & <0.001\end{array}$

Table II shows serum creatinine and serum uric acid levels in different groups of cases. Mean serum creatinine levels in Group A, Group B and Group C were $1.22 \pm 0.52 \mathrm{mg} / \mathrm{dL}, 1.36$ $\pm 0.42 \mathrm{mg} / \mathrm{dL}$ and $1.46 \pm 0.61 \mathrm{mg} / \mathrm{dL}$ respectively. There was no significant difference among the groups $(\mathrm{p}>0.05)$, but a rising trend was found from Group A to Group C. Mean serum uric acid levels in Group A, Group B and Group C were 7.22 \pm $2.33 \mathrm{mg} / \mathrm{dL}, 6.64 \pm 2.75 \mathrm{mg} / \mathrm{dL}$ and $7.19 \pm 2.49 \mathrm{mg} / \mathrm{dL}$ respectively without having any significant difference among the groups $(\mathrm{p}>0.05)$.

Table II: Serum creatinine and uric acid levels in different groups of cases

$\begin{array}{lcccc}\text { Parameters } & \begin{array}{c}\text { Group A } \\ (\mathrm{n}=14)\end{array} & \begin{array}{c}\text { Group B } \\ (\mathrm{n}=29)\end{array} & \begin{array}{c}\text { Group C } \\ (\mathrm{n}=37)\end{array} & \text { 'p' values } \\ \begin{array}{l}\text { Serum creatinine } \\ (\mathrm{mg} / \mathrm{dL})\end{array} & 1.22 \pm 0.52 & 1.36 \pm 0.42 & 1.46 \pm 0.61 & >0.05 \\ \begin{array}{l}\text { Serum uric acid } \\ (\mathrm{mg} / \mathrm{dL})\end{array} & 7.22 \pm 2.33 & 6.64 \pm 2.75 & 7.19 \pm 2.49 & >0.05\end{array}$

Pearson's correlation test was done to see the correlation of serum creatinine and uric acid levels with serum free thyroxine and serum TSH levels. But these parameters did not show significant correlation $(\mathrm{p}>0.05)$ with $\mathrm{FT}_{4}$ and $\mathrm{TSH}$.

\section{Discussion}

In this study, mean serum creatinine value in cases was found significantly higher than in the control subjects. This finding is consistent with the previous studies done by other investigators. ${ }^{7,10}$ Mean serum creatinine level in hypothyroid cases was found significantly greater in comparison to euthyroid value in a study done by Kreisman \& Hennessey. ${ }^{11}$ In another study on 14 newly diagnosed hypothyroid patients in Switzerland mean serum creatinine level was found elevated and decreased after thyroxine replacement therapy. ${ }^{12}$ In our study, serum creatinine values were found gradually increased from Group A to Group C. An apparent positive correlation was found between serum creatinine levels of different groups and severity of hypothyroidism, but it was not significant statistically.

In the present study mean serum uric acid level in hypothyroid subjects was significantly higher than in control subjects. This finding is consistent with the studies done by other investigators. They have also found serum uric acid level significantly elevated in hypothyroid patients. $.6,9,13,14$ In a study on 12 (twelve) induced hypothyroid rabbits, mean serum uric acid level was found higher in hypothyroid condition than in euthyroid condition. ${ }^{15}$ In our study, serum uric acid levels in Group A, Group B and Group C showed no difference and no correlation was found between serum uric acid levels and severity of hypothyroidism.

In our study, serum creatinine level was found significantly higher in hypothyroid patients. As the patients with chronic kidney diseases were excluded from the study and as our findings are consistent with some other studies, hypothyroidism should be taken into account in patients presenting with the biochemical abnormalities of chronic kidney diseases. Results of our study also suggest the findings of hyperuricemia in hypothyroid patients. Therefore, patients presenting with these biochemical abnormalities are recommended to be investigated to explore hypothyroidism. As our sample size was 
small and duration of study was limited, further studies with larger sample size and longer duration are also recommended.

\section{References}

1. Greenspan FS. The thyroid gland. In: Greenspan FS \& Gardner DG (eds). Basic \& Clinical Endocrinology. $7^{\text {th }}$ edn. New York: The McGraw-Hill Companies, 2004: 215-294.

2. Liberopoulos EN, Elisaf MS. Dyslipidemia in patients with thyroid disorders. [On-line] Available from: http://www.endocrine-society.gr/hormones/pdf/4 2002/05 liberopoulos.pdf, Greece: Moses S Elisaf, 2002.

3. Duntas LH. Thyroid disease and lipids. Thyroid 2002; 12: 287-293.

4. Walker BR, Toft AD. Endocrine disease. In: C Haslett, ER Chilvers, NA Boon \& NR Colledge (eds). Davidson's principles and practice of medicine. $19^{\text {th }}$ edn. London: Churchill Livingstone, 2002: 683-746.

5. Sawin CT, Castelli WP, Hershman JM, McNamara P, Bacharach P. The aging thyroid: thyroid deficiency in the Framingham study. Arch Intern Med 1985; 145: 1386-1388.

6. Kventy J, Heldgaard PE, Bladbjerg EM, Gram J. Subclinical hypothyroidism is associated with a low grade inflammation, increased triglyceride levels and predicts vascular disease in males below 50 years. Clin Endocrinol 2004; 61(2): 232-238.

7. Karanikas G, Schutz M, Szabo M, Becherer A, Wiesner
K, Dudczak R, Kletter K. Isotopic renal function studies in severe hypothyroidism and after thyroid hormone replacement therapy. Am J Nephrol 2004; 24(1): 41-45.

8. Birewar S, Oppenheimer M, Zawada ET Jr. Hypothyroid acute renal failure. S D J Med 2004; 57(3): 109-110.

9. Giordano N, Santacroce C, Mattii G, Geraci S, Amendola A, Gennari C. Hyperuricemia and gout in thyroid endocrine disorder. Clin Exp Rheumatol 2001; 19(6): 661-665.

10. Mooraki A, Bastani B. Reversible renal insufficiency, hyperuricemia and gouty arthritis in a case of hypothyroidism. Clin Nephrol 1998; 49(1): 57-60.

11. Kreisman SH, Hennessey JV. Consistent reversible elevations of serum creatinine levels in severe hypothyroidism. Arch Intern Med 1999; 159(1): 79-82.

12. Schmid C, Brandle M, Zwimpfer C, Zapf J, Wiesli P. Effect of thyroxine replacement on creatinine, insulinlike factor 1, acid-labile subunit, and vasular endothelial growth factor. Clin Chem 2004; 50(1): 228-231.

13. Erickson AR, Enzenauer RJ, Nordstrom DM, Merenich JA. The prevalence of hypothyroidism in gout. Am J Med 1994; 97(3): 231-234.

14. Yokogoshi Y, Saito S. Abnormal serum uric acid level in endocrine disorders. Nippon Rinsho 1996; 54(12): 3360-3363.

15. Dariyerli N, Andican G, Catakoglu AB, Hatemi H, Burcak G. Hyperuricemia in hypothyroidism: is it associated with post-insulin infusion glycemic response? Tohoku J Exp Med 2003; 199(2): 59-68. 